\title{
Yield of sweet potato fertilized with cattle manure and biofertilizer
}

\author{
Ademar P Oliveira ${ }^{1,5}$; João F Santos ${ }^{2}$; Lourival F Cavalcante ${ }^{1,5}$; Walter E Pereira ${ }^{1,5}$; Maria do Carmo CA \\ Santos $^{3,5}$; Arnaldo Nonato P Oliveiraa ${ }^{4,5}$; Natália V Silva ${ }^{4,5}$ \\ ${ }^{1}$ UFPB-CCA, C. Postal 02, 58397-000 Areia-PB; ${ }^{2}$ EMEPA, Lagoa Seca-PB; ${ }^{3}$ UFCG, Progr. Pós-graduação em Recursos Humanos, \\ 58104-533 Campina Grande-PB; ${ }^{4}$ Graduação em Agronomia, UFPB; ${ }^{5}$ Bolsista CNPq; ademar@pp.cnpq.br
}

\begin{abstract}
In Northeastern Brazil, the sweet potato is cultivated in small farms, in a family farming systems, constituting themselves an alternative way for the generation of food, employment and income. This study aimed to assess the effect of cattle manure levels and biofertilizer concentrations on the sweet potato cultivar White Queen productivity. The experiment was carried out from March to September 2007 at the EMEPA Experimental Station in Lagoa Seca, Brazil. The experimental design was randomized blocks, in split split plot $6 \times 4 \times 2+1$ scheme, with four replications. The plots consisted of cattle manure levels $\left(0,10,20,30,40\right.$ and $\left.50 \mathrm{t} \mathrm{ha}^{-1}\right)$, the subplot of biofertilizer concentrations $(0,15,30$ and $45 \%)$ and the sub subplots consisted of methods of biofertilizer application, to the soil or leaves. Also, there was an additional control treatment using $\mathrm{N}, \mathrm{P}$ and $\mathrm{K}$ mineral fertilizer. Commercial and total root productivity was evaluated. The levels of 30.8 and $31.2 \mathrm{t} \mathrm{ha}^{-1}$ of cattle manure were responsible for the highest commercial and total sweet potato root productivity (17.4 and $13.1 \mathrm{t} \mathrm{ha}^{-1}$, respectively). Biofertilizer concentrations of 29 and $28 \%$, applied to soil and to leaves provided, respectively, the greatest productivities of total roots (15.4 and 13.1 $\mathrm{t} \mathrm{ha} \mathrm{a}^{-1}$ ), whereas concentrations of 30 and $27 \%$, also applied to soil and leaves were responsible, respectively, for the highest commercial root productivity (11 and $9.7 \mathrm{tha}^{-1}$ ).
\end{abstract}

Keywords: Ipomoea batatas, organic fertilization, productivity.

\section{RESUMO}

Produção da batata-doce adubada com esterco bovino e biofertilizante

Na região Nordeste do Brasil, a batata-doce é principalmente plantada por pequenos produtores em sistema de agricultura familiar, constituindo-se numa alternativa de alimentação e geração de emprego e renda. Este trabalho teve por objetivo avaliar o efeito das doses de esterco bovino e de concentrações de biofertilizante sobre a produtividade da batata-doce, cultivar Rainha Branca. O experimento foi conduzido no período de março a setembro de 2007 na Estação Experimental da EMEPA, em Lagoa Seca-PB, Brasil. O delineamento experimental foi de blocos casualizados, em esquema de parcelas subdivididas $6 \times 4 \times 2+1$, em quatro repetições. A parcela foi constituída de doses de esterco bovino $(0,10,20,30,40$ e $50 \mathrm{t}$ $\left.\mathrm{ha}^{-1}\right)$, a subparcela de concentrações de biofertilizante $(0,15,30$ e $45 \%$ ). A subsubparcela foi representada pelas formas de aplicação do biofertilizante no solo e via foliar, aos 20, 30, 40, 50, 60, 70, 80, 90 e 100 dias após o plantio. Foi aplicado um tratamento adicional com adubação N, P e K. Foram avaliadas produtividade total e comercial de raízes. As doses de 30,8 e 31,2 t ha ${ }^{-1}$ de esterco bovino resultaram em máximas produtividades total e comercial de raízes de batata-doce, 17,4 e $13,1 \mathrm{t} \mathrm{ha}^{-1}$, respectivamente. As concentrações de 29 e $28 \%$ de biofertilizante, aplicadas no solo e via foliar, respectivamente, proporcionaram as maiores produtividades total de raízes $(15,4 \mathrm{e}$ $13,1 \mathrm{t} \mathrm{ha}^{-1}$ ) e as concentrações de 30 e $27 \%$, também aplicadas no solo e via foliar foram responsáveis, respectivamente, pelas máximas produtividades comerciais de raízes (11 e 9,7 t ha ${ }^{-1}$ ).

Palavras-chave: Ipomoea batatas, adubação orgânica, produtividade.

\section{(Recebido para publicação em 26 de novembro de 2008; aceito em 9 de julho de 2010)} (Received on November 26, 2008; accepted on Juy 9, 2010)

$\mathrm{S}^{\mathrm{s}}$ weet potato is the fourth most consumed vegetable in Brazil. It is cultivated in all the Brazilian geographic regions, especially in the South and in the Northeast ones. In the Brazilian Northeast region, sweet potato plays an important social role, since it is an energetic food source, which is part of the food chain of the poorest social strata. Additionally, it is more cultivated and spread in the regions which are close to the big consumer centers (Soares et al., 2002). Besides of its importance, sweet potato presents a low average yield $\left(6,8 \mathrm{t} \mathrm{ha}^{-1}\right)$, caused, among other reasons, by the poor knowledge about the crop organic and mineral nutritional necessities (Oliveira et al., 2007).

The utilization of animal organic manure is believed to improve the quality of soil and to provide economic benefits for the vegetable crop growers, since it promotes soil fertility by the nitrogen accumulation, increasing the mineralization potential of this element and, consequently, improving the nitrogen availability to the crop (Galvão et al., 1999). Nonetheless, the required manure dose will depend on the soil type, texture, structure and organic matter content (Trani et al.,1997).

The vegetable crops are benefited by the utilization of organic manure, which improves crop quality and productivity. These benefits are consequences of the improvement of many physical, chemical and biological soil properties, which is provided by the application of organic fertilizers (Ferreira et al., 1993). The cattle manure is the most utilized source, especially on soils with low organic matter content (Filgueira, 2000).

Positive effects of organic fertilization on productivity have been obtained from 
some vegetable crops whose roots comprise the commercialized product. For carrot, Praxedes (2000) verified higher production with treatments which received cattle manure and cattle manure plus biofertilizer, of 22.0 and 20.3 t ha-1 of roots. For sweet potato, Hollanda (1990) obtained the highest economic efficiency of root production with the application of $40 \mathrm{tha}^{-1}$ of cattle manure.

Another useful and cheap procedure is the employment of biofertilizers which are prepared through the aerobic digestion of organic material. Those liquid fertilizers have been utilized in the organic agriculture in substitution to the mineral fertilizers (Fernandes et al., 2000) in order to sustain the nutritional balance of the plants and make them less susceptible to the pests and pathogens (Santos, 2001).

In short cycle crops, as the vegetable crops, the utilization of biofertilizers must be carried out weekly through spray application in order to provide a rapid and efficient nutrient complementation for a good plant development. Pinheiro \& Barreto (2000) obtained improvement of commercial production of cucumber, eggplant, tomato, lettuce and sweet pepper as a result of the application of a biofertilizer produced with cattle manure at $20 \%$ in greenhouse and in field. In sweet potato, there is almost no information about the utilization of biofertilizers. It evidences the necessity of researches in order to make the biofertilizer utilization for this crop a feasible alternative fertilization method.

The present research work aimed at evaluating the production of sweet potato depending on different doses of cattle manure and different concentrations of biofertilizers applied to soil or to plant leaf.

\section{MATERIAL AND METHODS}

The experiment was carried out from May to September 2007 at the EMEPA experimental station in Lagoa Seca, Paraíba State, Brazil, 60 58'12" South latitude, $32^{\circ} 42$ ' $15^{\prime}$ ' West longitude and $534 \mathrm{~m}$ high (Gondim \& Fernandes, 1980). According to the
Gaussen bioclimatic classification, the 3DTH northeastern sub-dry bioclimate predominates over this area, which presents an average annual rainfall of about $1,400 \mathrm{~mm}$.

According to the Köppen classification, the climate is AS', characteristically hot and humid, which presents rainfall events during autumn and winter. The soil, according to Embrapa (1999), is the Neossolo Regolítico Psamítico Típico, with the following chemical attributes: $\mathrm{pH}=6.5$; $\mathrm{P}=94.76 \mathrm{mg} \mathrm{dm}^{-3} ; \mathrm{K}=121.83 \mathrm{mg} \mathrm{dm}^{-3}$; $\mathrm{Ca}=3.50 \mathrm{cmol}_{\mathrm{c}} \mathrm{dm}^{-3} ; \mathrm{Mg}=0.75 \mathrm{cmol}_{\mathrm{c}}$ $\mathrm{dm}^{-3}$ and organic matter $=13.1 \mathrm{~g} \mathrm{~kg}^{-1}$. The cattle manure chemical attributes were: $\mathrm{N}=7.20 \mathrm{~g} \mathrm{dm}^{-3} ; \mathrm{P}_{2} \mathrm{O}_{5}=3.60 \mathrm{~g} \mathrm{~kg}^{-1}$; $\mathrm{K}_{2} \mathrm{O}=4.10 \mathrm{~g} \mathrm{~kg}^{-1} ; \mathrm{C}=105.85 \mathrm{~g} \mathrm{dm}^{-3}=$ $\mathrm{C} / \mathrm{N}=14 / 1$ and organic matter $=182.07$ $\mathrm{g} \mathrm{kg}^{-1}$. The biofertilizer presented the following chemical attributes: $\mathrm{N}=8.2$ $\mathrm{g} \mathrm{kg}^{-1} ; \mathrm{P}=0.44 \mathrm{~g} \mathrm{~L}^{-1} ; \mathrm{K}=0.65 \mathrm{~g} \mathrm{~L}^{-1} ; \mathrm{S}$ $=0.54 \mathrm{~g} \mathrm{~L}^{-1} ; \mathrm{Ca}=0.93 \mathrm{~g} \mathrm{~L}^{-1}$ and $\mathrm{Mg}=$ $0.92 \mathrm{~g} \mathrm{~L}^{-1}$.

The randomized blocks experimental design in the split split plot scheme $6 \mathrm{x}$ $4 \times 2+1$ with four replications was adopted. The main plots were doses of cattle manure $(0,10,20,30,40$ and 50 $\left.\mathrm{t} \mathrm{ha}^{-1}\right)$, the subplots were biofertilizer concentrations $(0,15,30$ and $45 \%)$, and the sub subplots were two methods of biofertilizer application (to the soil or to the plant leaves). There was, also, a control treatment with mineral N, P and $\mathrm{K}$ fertilization.

The sub subplots were constituted by five 3.50-meter-length furrows, of which the central furrow and the two plants of each end were eliminated. Thus, the sub subplot useful area was constituted by four 2.5-meter-length furrows (40 plants and $10 \mathrm{~m}^{2}$ ), the subplots were constituted by 16 furrows (160 plants and $40 \mathrm{~m}^{2}$ ) and the main plots were constituted by 96 furrows (960 plants and $240 \mathrm{~m}^{2}$ ).

The cattle manure was mixed to soil fifteen days before planting and the biofertilizer treatments were applied to soil and to the plant leaf 20,30,40, $50,60,70,80,90$ and 100 days after planting.

In order to meet the necessity of the useful plants into the tertiary plots, three liters of solution (biofertilizer plus water) were necessary for each form of application (to soil and to plant leaves). $750 \mathrm{~L} \mathrm{ha}^{-1}$ were necessary for each concentration treatment.

The biofertilizer was prepared following the methodology of Santos (1992), which was constituted by fermentation during 30 days of a mixture of fresh cattle manure and water in the proportion of $50 \%$ (volume/volume $=$ $\mathrm{v} / \mathrm{v}$ ), into a plastic container without air. In addition to these ingredients, we added $2 \%$ of plant ash, $2.5 \%$ of chicken litter and $1 \%$ of limestone. To make the system anaerobic, the mixture was poured into a 200-liter container, up to $15-20 \mathrm{~cm}$ of the top. Then, the container was hermetically sealed and a hose was introduced through the lid. The other hose end was immersed into water in a 20-centimeter container, to allow the release of gases.

The plots corresponding to the mineral $\mathrm{N}, \mathrm{P}$ and $\mathrm{K}$ fertilization were applied, at the planting moment, $30 \mathrm{~kg}$ $\mathrm{ha}^{-1}$ of $\mathrm{N}$ and $10 \mathrm{~kg} \mathrm{ha}^{-1}$ of $\mathrm{K}_{2} \mathrm{O}$. The topdressing was constituted by $60 \mathrm{~kg} \mathrm{ha}^{-1}$ of $\mathrm{N}$ and $20 \mathrm{~kg} \mathrm{ha}^{-1}$ of $\mathrm{K}_{2} \mathrm{O}$ split in equal parts at 30 and 45 days after planting. As sources of $\mathrm{N}$ and $\mathrm{K}_{2} \mathrm{O}$, amonium sulphate and potassium chloride were utilized. Considering the $\mathrm{P}_{2} \mathrm{O}_{5}$ level presented by the soil, phosphate fertilization was not carried out.

Forty-centimeter stems of the Rainha Branca cultivar of sweet potato were used for planting. These stems, which were obtained from a nursery close to the experimental area, were cut one day before planting. At planting, they were buried to $10-12 \mathrm{~cm}$ depth from its basis with a little hook and they were spaced $0.80 \times 0.30 \mathrm{~m}$.

Irrigation was carried out twice a week during the dry periods, providing adequate moisture conditions for the plant development. Hand hoeing was carried out in order to keep the experimental area free from weeds. Considering the absence of pests and diseases, actions for their management were not performed.

Harvesting was carried out 110 days after planting, at the sweet potato physiological maturity point, and total and commercial productivity of roots were evaluated. Commercial 
productivity referred to the weight of uniform smooth roots, weighting $80 \mathrm{~g}$ or more, according to Embrapa (1995). The results were submitted to variance and regression analysis at 5\% of significance.

\section{RESULTS AND DISCUSSION}

Cattle manure dose, biofertilizer concentration and the application method influenced significantly $(\mathrm{p}<0.01)$ total and commercial yield of sweet potato roots. In regression analysis, the average values of productivity depending on cattle manure doses and biofertilizer concentrations matched quadratic models (Figures 1 and 2).

The highest total and commercial productivity of roots were 17.4 and 13.1 t ha- ${ }^{-1}$ obtained with 30.8 and $31.2 \mathrm{t} \mathrm{ha}^{-1}$ of cattle manure, which represented a yield improvement of 35.2 and $41 \%$, respectively, in comparison to the productivity obtained without cattle manure application (Figure 1). Santos et al. (2006) obtained improvement of 54\% for commercial productivity of sweet potato roots through the application of $32 \mathrm{t} \mathrm{ha}^{-1}$ of cattle manure. The highest yield obtained by these authors for commercial root production percentage is, possibly, due to the higher dose of cattle manure and to its higher content of nutrients $\left(\mathrm{N}=8.2 \mathrm{~g} \mathrm{~kg}^{-1} ; \mathrm{P}=5.2 \mathrm{~g}\right.$ $\mathrm{kg}^{-1}$ and $\mathrm{K}=4.9 \mathrm{~g} \mathrm{~kg}^{-1}$ ), in relation to the cattle manure used in the present research work.

Towards the biofertilizer concentration, the highest total root yields were 15.4 and $13.1 \mathrm{tha}^{-1}$, obtained with the concentrations of 29 and $28 \%$, applied to soil and to leaves, respectively (Figure 2). Nevertheless, the concentrations of 30 and $27 \%$, also applied to soil and to leaves resulted, respectively, in the highest commercial yields of roots (11.0 and $9.7 \mathrm{t} \mathrm{ha}^{-1}$ ) (Figure 3). Whereas the total productivities were respectively 27.7 and $24.4 \%$ higher in comparison to the treatments without biofertilizers, these values were of 29.4 and $25.3 \%$ for the commercial yield.

The biofertilizer applied to soil improved total and commercial productivity in 2.3 and $1.3 \mathrm{t} \mathrm{ha}^{-1}$

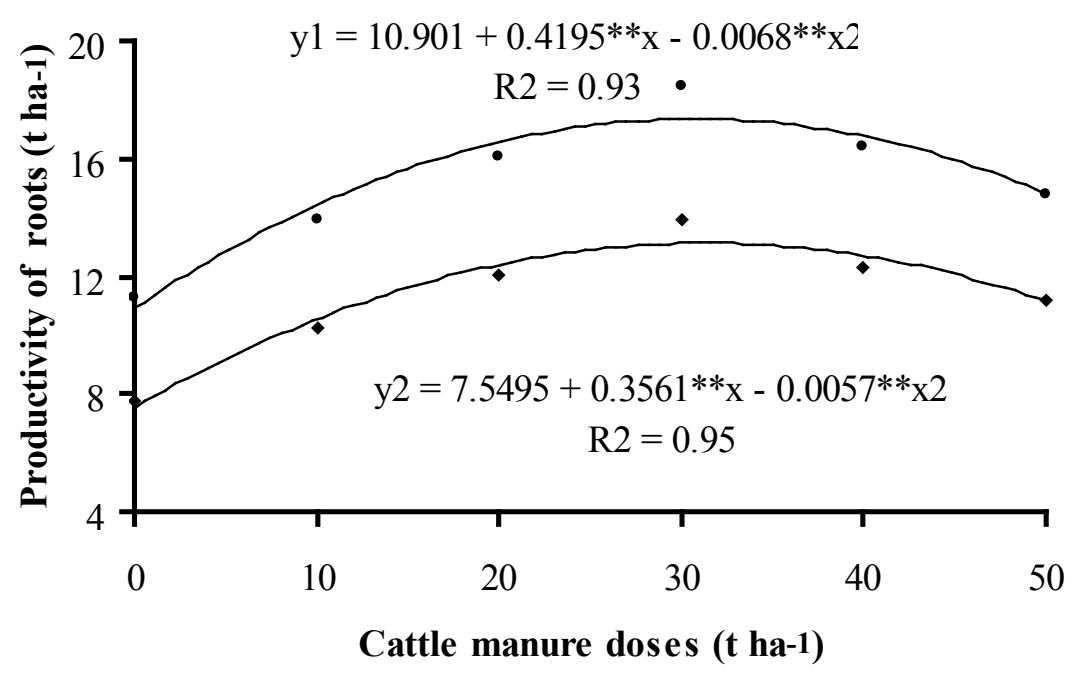

Figure 1. Commercial $\left(\mathrm{y}_{2}\right)$ and total $\left(\mathrm{y}_{1}\right)$ productivity of sweet potato roots according to cattle manure levels (produtividade total $\left(\mathrm{y}_{1}\right)$ e comercial $\left(\mathrm{y}_{2}\right)$ de raízes de batata-doce em função de doses de esterco bovino). Lagoa Seca, EMEPA, 2007.

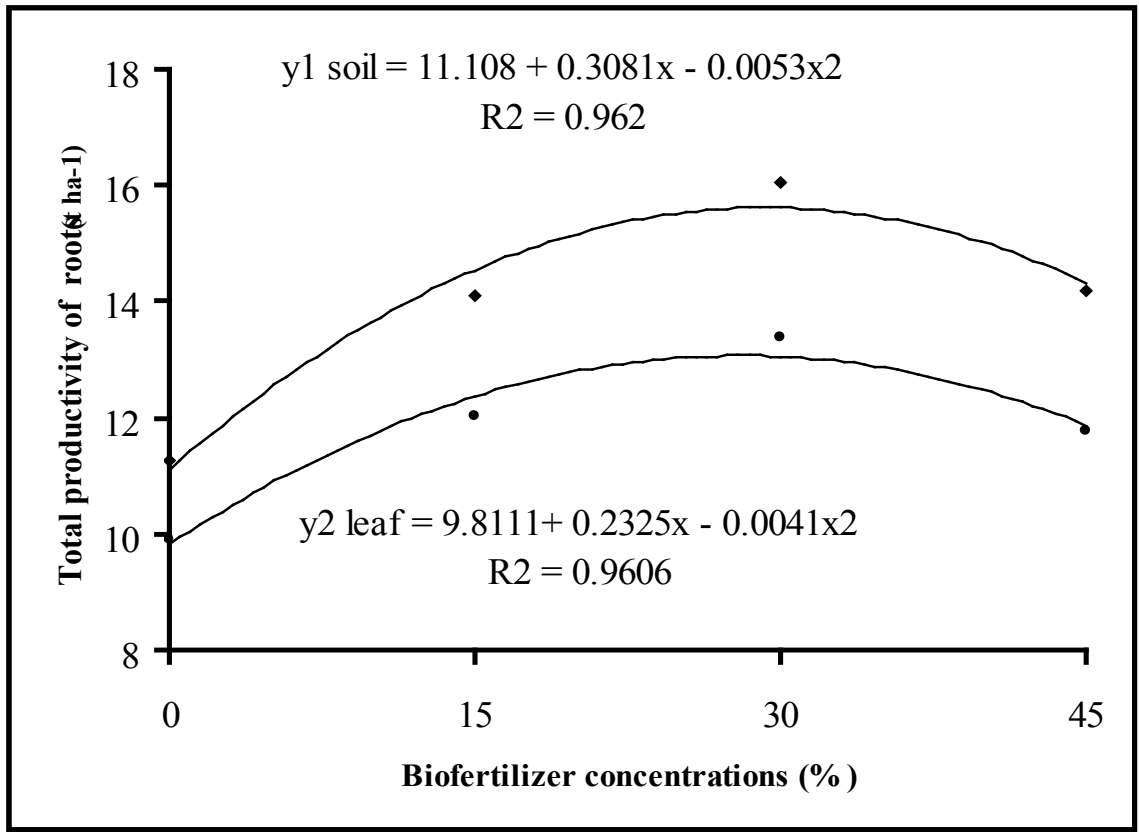

Figure 2. Total productivity of sweet potato roots according to biofertilizer concentrations application in the soil and on leaves (produtividade total de raízes de batata-doce em função de concentrações de biofertilizante aplicado no solo e via foliar). Lagoa Seca, EMEPA, 2007.

in comparison to its application to the plant leaves (Figures 2 and 3). However, Oliveira et al. (2007) obtained productivity of $12.9 \mathrm{tha}^{-1}$ of commercial roots of sweet potato with the utilization of cattle manure and a concentration of $20 \%$ of biofertilizer. On the other hand, Barbosa (2005) produced $13.4 \mathrm{t} \mathrm{ha}^{-1}$ of commercial sweet potato roots with the application of biofertilizer at the concentration of $20 \%$.
The highest commercial root productivities obtained through the application of cattle manure and biofertilizer were higher than the Paraíba State average productivity $\left(6,8 \mathrm{t} \mathrm{ha}^{-1}\right)$ (Silva et al., 2002) and the national average productivity $10 \mathrm{t} \mathrm{ha}^{-1}$ (Soares et al., 2002). It demonstrates those organic insumes are efficient for the improvement of sweet potato productivity. The highest productivity 


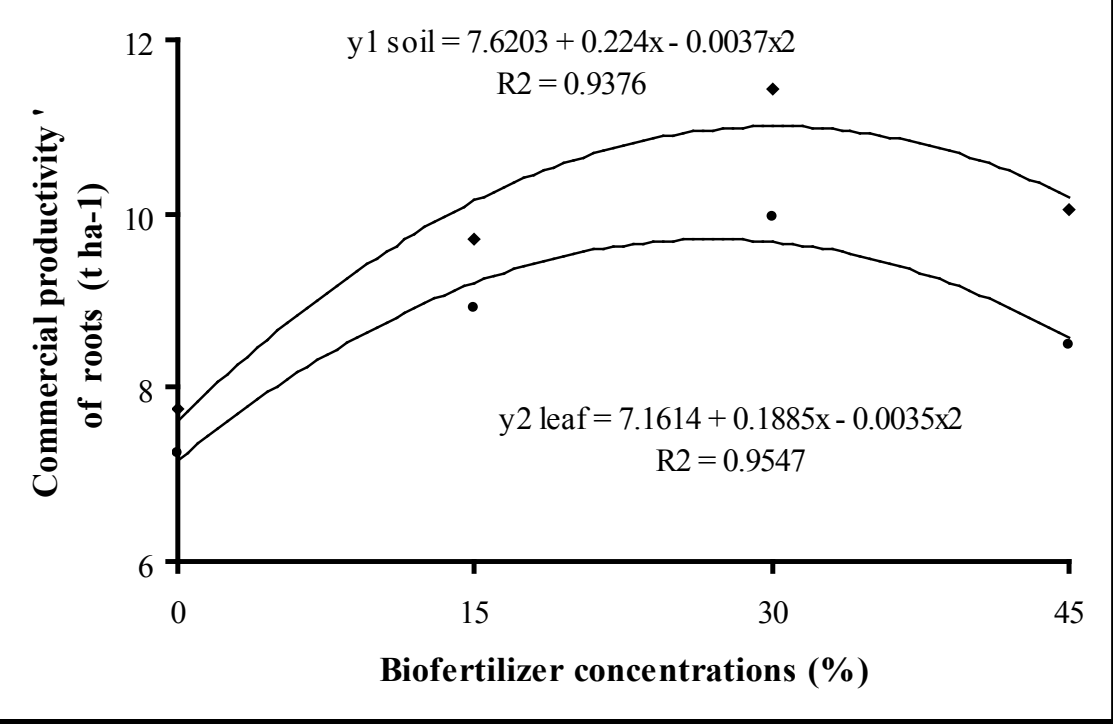

Figure 3. Commercial productivity of sweet potato roots according to biofertilizer concentrations application in the soil and on leaves (produtividade comercial de raízes de batata-doce com concentrações de biofertilizante aplicado no solo e via foliar). Lagoa Seca, EMEPA, 2007.

obtained through the utilization of cattle manure and biofertilizer applied to soil overcame the national average productivity in 3.1 and $1.0 \mathrm{t} \mathrm{ha}^{-1}$, respectively. Therefore, these nutrient sources can be recommended to the sweet potato organic fertilization, mainly the cattle manure.

The cattle manure efficiency for improving the yield of sweet potato commercial roots is, possibly, related to its chemical composition, to the improvement of the physical and biological properties of the soil and to the supply of nutrients such as nitrogen, phosphorus and potassium. Considering the low organic matter content of the soil $\left(13.19 \mathrm{~g} \mathrm{~kg}^{-1}\right)$, the positive results obtained through the utilization of cattle manure are related to the improvement of the soil cation exchange capacity and the supply of nutrients to the sweet potato plant (Varanine et al., 1993; Filgueira, 2000).

The sweet potato response to the utilization of the biofertilizer can be related to the fact that the application of liquid organic fertilizers to the vegetable crops can provide higher nutrient absorption (Gabaltti et al., 1991; Souza \& Resende, 2003). The higher sweet potato productivities obtained through the application of biofertilizer to the soil can be related to the balanced supply of macro and micronutrients, to the longer period of contact between the root and the biofertilizer, to the lower evapotranspiration and to the higher absorption of water and nutrients by the sweet potato plant (Cavalcante \& Lucena, 1987; Galbiatti et al., 1991).

The cattle manure doses and the biofertilizer concentrations which provided the highest productivities, in addition to the initial soil nutrient content were enough to match the sweet potato nutritional necessities. The right use of organic fertilizers can supply the plant necessities for some macronutrients (Raij, 1991). Likewise, Soares et al. (2002) and Santos et al. (2006) reported that cattle manure application improved the production of tuber roots. Furthermore, Oliveira et al. (2007) reported improvement of tuber roots productivity with the application of biofertilizers.

There was no significant difference between organic and mineral N, P and $\mathrm{K}$ fertilization. However, according to Filgueira (2000), sweet potato presents good responses to the application of nitrogen, phosphorus and potassium. In the present work, the absence of responses to the utilization of $\mathrm{N}, \mathrm{P}$ and $\mathrm{K}$ can be related to the high contents of $\mathrm{P}\left(94,76 \mathrm{mg} \mathrm{dm}^{-3}\right)$ and $\mathrm{K}(126,83$ $\mathrm{mg} \mathrm{dm}{ }^{-3}$ ), in addition to the quantity of nutrients presented by the biofertilizer and the cattle manure, which indicates these organic fertilizers match the nutritional necessities of the sweet potato plant.

Some authors verified sweet potato responses to the application of mineral fertilizers. Oliveira et al. (2006a) and Brito et al. (2006) obtained sweet potato production improvement as effect of application of phosphorus and potassium, respectively. Therefore, the absence of sweet potato responses to the $\mathrm{N}, \mathrm{P}$ and $\mathrm{K}$ fertilization can also be explained by nutrient leaching due to the excessive rainfall during the experiment conduction. According to MeIo et al. (2000), nutrients from fertilizers can be easily leached, especially nitrogen. Oliveira et al. (2006b) reported lower production of sweet potato commercial roots with high occurrence of rainfall.

Thus, the results which were obtained in the present work indicate cattle manure and biofertilizer can be a good alternative for the sweet potato organic fertilization. However, further research should be carried out under different soil types and rainfall levels in order to check them.

\section{REFERENCES}

BRITO CH; OLIVEIRA AP; ALVES AU; DORNELAS CSM; SANTOS JF; NÓBREGA JPR. 2006. Produtividade da batata-doce em função de doses de $\mathrm{K} 2 \mathrm{O}$ em solo arenoso. Horticultura Brasileira 24: 320-323.

CAVALCANTE LF; LUCENA ER. 1987. Fosfogesso e biofertilizante bovino num solo salino sódico sobre germinação, crescimento e produção de matéria seca de Vigna (Vigna unguiculata L. WALP). Revista Tecnologia e Ciência 1: 16-20.

EMBRAPA. Centro Nacional de Pesquisa de Hortaliças. 1995. Cultivo da batata-doce (Ipomoea batatas (L.) Lam). (Instruções Técnicas, 7).

EMBRAPA. Centro Nacional de Pesquisa de Solos. 1999. Sistema Brasileiro de Classificação de Solos. Brasília: Produções de Informações. 412p.

FERNANDES MCA; LEAL MAA; RIBEIRO RLD; ARAÚJO ML; ALMEIDA DL. 2000. Cultivo protegido do tomateiro sob manejo orgânico. A Lavoura 634: 44-45.

FERREIRA ME; CASTELLANE PE; CRUZ MCP. 1993. Nutrição e adubação de hortaliças. Piracicaba: Potafos. 487p.

FILGUEIRA FAR. Manual de Olericultura. 2000. Viçosa: UFV. 402p.

FREITAS SP; SEDIYAMA T; SEDIYAMAMAN; 
SILVAAA. 1999. Efeito de composto orgânico na produção da batata-doce (Ipomoea batatas L.) Lam., na incidência de plantas daninhas e na eficiência do diuron. Revista Ceres 46: 251-265.

GALBIATTI JA; BENECASA M: LUCAS JÚNIOR J; JOSÉ LJ. 1991. Efeitos da incorporação de efluentes de biodigestor sobre alguns parâmetros do sistema solo-planta, em milho. Revista Científica 19: 105 -118.

GALVÃO JCC; MIRANDA GV; SANTOS IC. 1999. Adubação orgânica. Cultivar 9: 38-41.

GONDIM AWA; FERNANDEZ B. 1980. Probabilidade de chuvas para o município de Areia-PB. Agropecuária Técnica 1: 55-63.

HOLLANDA JS. 1990. Preparo do solo, adubação e plantio de batata-doce. In: ENCONTRO DE PROFESSORES, PESQUISADORES E EXTENCIONISTAS DE OLERICULTURA DO RIO GRANDE DO NORTE, Mossoró,. Anais ... Mossoró, p.14-26.

OLIVEIRA AP; SILVA JEL; PEREIRA WE; BARBOSA LJN; OLIVEIRA ANP. 2006a. Características produtivas da batata-doce em função de doses de $\mathrm{P}_{2} \mathrm{O}_{5}$, de espaçamentos e de sistemas de plantio. Ciência e Agrotecnologia 30: 611-617.

OLIVEIRA AP; MOURA MF; NOGEIRA DH;
CHAGAS NG; BRAZ MSS; OLIVEIRA MRT; BARBOSA JA. 2006b. Produção de raízes de batata-doce em função do uso de doses de $\mathrm{N}$ aplicadas no solo e via foliar. Horticultura Brasileira 24: 27-28.

OLIVEIRA AP; BARBOSA AH; PEREIRA WE; OLIVEIRA ANP. 2007. Produção de batata-doce adubada com esterco bovino e biofertilizante. Ciência Agrotécnica 31: 1722-1728.

PINHEIRO S; BARRETO SB. 2000. “ $M b-4$ " - Agricultura Sustentavel, Trofobiose e Biofertilizantes. MIBASA. 273 p.

PRAXEDES MG. 2000. Avaliação de características agronômicas da cenoura (Daucus carota L.) cultivada com biofertilizante. Areia: UFPB-CCA. 22p (Monografia graduação).

RAIJ BV. 1991. Fertilidade do Solo e Adubação. Piracicaba: Potafós. 343p.

SANTOS ACV. 1992. Biofertilizante líquido, o defensivo da natureza. EMATER-Rio. (Agropecuária Fluminense, 8).

SANTOS ACV. 2001. A ação múltipla do biofertilizante líquido como ferti fitoprotetor em lavouras comerciais. In: ENCONTRO DE PROCESSOS DE PROTEÇÃO DE PLANTAS, 1. Anais... Botucatu, p. 91-96.
SANTOS JF; OLIVEIRA AP; ALVES AU; DORNELAS CSM; BRITO CH; NÓBREGA JPR. 2006. Produção de batata-doce adubada com esterco bovino em solo com baixo teor de matéria orgânica. Horticultura Brasileira 24: 103-106.

SILVA JBC; LOPES CA; MAGALHÃES JS. 2002. Cultura da batata-doce. In: CEREDA M. P. Agricultura: Tuberosas amiláceas Latino Americanas, São Paulo: Cargill, p. 449-503.

SOARES KT; MELO AS; MATIAS EC. 2002. A cultura da batata-doce (Ipomoea batatas (L.) Lam). EMEPA-PB. (Documentos, 41).

SOUZA JL; RESENDE P. Manual de horticultura orgânica. Viçosa: Aprenda fácil, p.564 il, 2003.

TRANI PE; TAVARES M; SIQUEIRA WJ; SANTOS RR; BISÃO LL; LISBÃO RS. 1997. Cultura do alho. Recomendação para seu cultivo no Estado de São Paulo. Campinas: IAC. $26 \mathrm{p}$.

VARANINE Z; PINTON R; BIASE MG; ASTOLFI S; MAGGIONI A. 1993. Low molecular weight humic substances stimulate $\mathrm{H}+$-ATPase activity of plasma membrane vesicles isolated from oat (Avena sativa L.) roots. Plant and Soil 153: 61-69. 